\title{
Liver Changes Caused by Sars-CoV-2
}

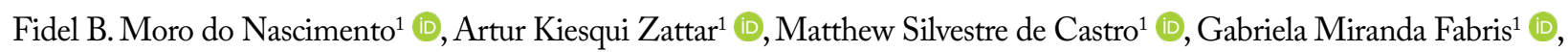
Vitória Carolina Bitencourt da Silva ${ }^{1}\left(\mathbb{D}\right.$, Maria Eduarda Costa Oliveiraa $^{1}\left(\mathbb{D}\right.$, Lucas de Oliveira Rodrigues $^{1}(\mathbb{D}$, Marina Zanatta

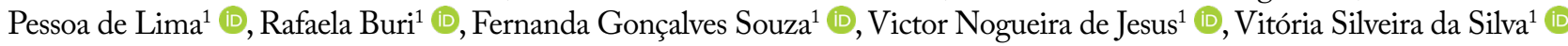

1. Centro Universitário de Várzea Grande Rớr Várzea Grande (MT), Brasil.

doi https://doi.org/10.53855/bjt.v25i1.427_en

Correspondence author:

fidel.moro1@gmail.com

\section{Section Editor}

Ilka Boin

Received

Dez. 12, 2021

Approved

Jan. 27, 2022

Conflict of interest

Nothing to declare.

\section{How to Cite}

Nascimento FBM, Zattar AK, Castro

MS, Fabris GM, Silva VCB, et al. Liver

Changes Caused by Sars-CoV-2. BJT.2022;

25(01): e0622. https://doi.org/10.53855/bjt.

v25i1.427_en

eISSN

2764-1589

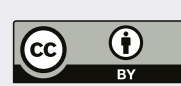

\begin{abstract}
With the Sars-CoV-2 virus endemic, many individuals with preexisting liver diseases such as liver cirrhosis and chronic liver diseases have become exposed to decompensation due to the virulence of exposure and individual susceptibility to the new coronavirus infection. The direct cytotoxicity of the Sars-CoV-2 virus occurs through its replication in liver cells, given by the binding of the agent to the target cells by the expression of the angiotensin-converting enzyme 2 (ACE2), which is the main mediator of viral replication in infected patients. by Covid-19. As a consequence, proinflammatory cytokines increase and can cause hypoxia and systemic ischemia. In association with lymphopenia and a decrease in CD4+ T-cell levels, patients may progress to decompensation or worsening of the infectious condition, with chronic liver failure worsening since the first week and, thus, a decrease in survival. Patients pre-diagnosed with cirrhosis and infected with the Covid-19 virus have greater liver involvement and worse prognosis and, therefore, deserve special monitoring, being carefully evaluated in order to enable the reduction of liver damage caused by the infection.
\end{abstract}

Descriptors: Sars-CoV-2; Covid-19; Hepatocytes; Pandemics; Cytokine release syndrome; Hepatic cirrhosis; hypoxia.

\section{INTRODUCTION}

Covid-19 is a highly contagious infection that emerged as an endemic in December 2019 with its first cases in the Chinese province of Wuhan and then evolved into a pandemic. ${ }^{1}$ Covid-19 is a highly contagious infection that emerged as an endemic in December 2019 with its first cases in the Chinese province of Wuhan and then evolved into a pandemic. ${ }^{2,3}$

With SARS-CoV-2 contagion, the single-stranded RNA virus initiates pathogenicity in the individual. The process of viral invasion occurs through the high affinity binding of the $S$ protein present in the virus with the angiotensinconverting enzyme 2 (ACE2), which is highly present in the airways. This binding enables penetration into alveolar target cells through the process of clathrindependent endocytosis, thus enabling viral fusion and replication within alveolar cells and their propagation to other lung segments and other systems that express ACE2. ${ }^{4,5}$ The systemic involvement caused by infection by Sars-CoV-2 was observed in cardiac, renal, neurological and hepatic cells, the latter being verified in several studies by altering tests of proteins that are markers of liver injury. ${ }^{6-12}$

The clinical picture of viral infection is versatile, ranging from asymptomatic to classic symptomatic cases, such as fever, dry cough, fatigue, expectoration, dyspnea, sore throat, headache, myalgia or arthralgia, nasal congestion, diarrhea, hemoptysis, and conjunctival congestion. ${ }^{13}$ The severity of the infection varies according to the 
virulence of exposure and the susceptibility of the affected individual. The classification of risk factors for more severe cases of the new coronavirus are: advanced age, obesity, diabetes mellitus, systemic arterial hypertension, chronic respiratory diseases, cardiovascular diseases and neoplasms, highlighting the importance of comorbidities in patients. ${ }^{14}$

Liver injury is an important marker of worsening infection in individuals affected by the new coronavirus infection, in addition to being characterized as a comorbidity in patients who already have preexisting liver diseases, such as decompensated liver cirrhosis and chronic liver diseases. ${ }^{15-17}$ This directly reflects not only the damage caused to the liver at the time of infection, but also the long-term follow-up of patients, as demonstrated by the APCOLIS study. ${ }^{18}$ In this study on the evolution of preexisting liver disease in patients with SARS-CoV-2 infection, acceleration of liver damage was observed in patients with cirrhosis when compared to individuals without comorbidities. ${ }^{18}$

This study performs a non-systematic review of the mechanisms of liver injury caused by Sars-CoV-2 and its association with the pre-diagnosis of liver cirrhosis, seeking to analyze the worsening of pre-existing liver injury, possible laboratory investigation methods and prognoses of these patients in post-infection by Covid- 19 .

\section{MECHANISMS OF HEPATIC INJURY BY SARS-COV-2}

In order to understand how Covid-19 can affect the liver, a cohort study was carried out comparing several laboratory tests among infected patients who did not have liver complications. ${ }^{19}$ Although the mechanism of liver injury by Covid-19 has not been fully understood, the pathological investigation of an infected patient demonstrated the presence of moderate steatosis, leukocyte infiltration in the lobular and portal areas, focal necrosis and sinusoidal congestion. ${ }^{19}$

\section{Direct viral cytotoxicity to the liver}

Direct cytotoxicity due to virus replication in liver cells is due to the binding of Sars-CoV-2 to target cells, demonstrated by the expression of ACE2, which is the main mediator of viral replication in patients infected with Sars-CoV-2. ${ }^{20}$

A study carried out by the University Medical Center of Groningen, in the Netherlands, analyzed the distribution of ACE2 in body tissues, detecting the presence of these proteins in hepatocytes. ${ }^{21}$ Recently, in 2020 , there was the publication of a cohort study that revealed a significant enrichment of ACE2 expression in the liver, mainly in the cells that make up the bile ducts (cholangiocytes), observing an average 20 times higher in relation to the expression level in hepatocytes, while in Kupffer cells ACE2 was not detected. ${ }^{22}$ Reinforcing this proposal, biopsy samples collected from patients with Covid-19 show moderate microvesicular steatosis and mild lobular and portal activity. ${ }^{23}$

Patients infected with the virus during hospitalization in Wuhan demonstrated elevated aspartate aminotransferase (AST), alanine aminotransferase (ALT) and lactate dehydrogenase (LDH) levels, suggesting an injury linked to the progression of Sars-CoV-2. ${ }^{24}$

\section{Immune-mediated liver injury by the body's systemic response}

Among the possible explanations for such processes is the immune-mediated injury by the systemic inflammatory response, according to the report of a study that showed increased pro-inflammatory cytokines mainly in severe cases of Covid-19, which could cause hypoxia and systemic ischemia. ${ }^{25}$

The exacerbated increase in inflammatory cytokines has been described as a cytokine storm, and together, lymphopenia and decreased levels of CD4+ T cells, common findings in patients infected with Sars-CoV-2, may be associated with the intensity of the disease and mortality. ${ }^{26}$

One of the cohort studies characterized, in inflammatory cytokines, the presence of kinetic alterations, including IL-6, IL-2, IL-4, IFN- $\gamma$ and TNF- $\alpha$ in the participants' serum. Thus, it was observed that in patients with characteristics of mild Sars-CoV-2 infection, fluctuations in the serum levels of these cytokines were considerably smaller than in critically ill patients, who had significant fluctuations. ${ }^{27}$

With the exception of IL-6, all other cytokines reached their peak in serum between three and six days after the onset of the disease, however the levels of IL- 6 and IL-10 showed a sustained increase in the group with a more severe condition if compared to the other with a milder infection. In this logic, it was seen that the decrease in T cells in Covid-19 can result in worsening inflammatory responses, while the normalization of the number of these cells can decrease inflammatory responses. Reinforcing this hypothesis, the $\mathrm{T}$ cell count pointed to an inversely proportional correlation between its values compared to the levels of cytokines in the peripheral blood of critically ill patients, because when the T cells were at the lowest levels, the peak in the serum levels of IL- 10, IL-2, IL-4, TNF- $\alpha$ and IFN- $\gamma$, approximately between the fourth and sixth day. ${ }^{27}$ 
In view of the research, a possible protagonist role of IL-6 in the process is observed: $30.39 \%$ of participants with mild infection by Sars-CoV-2 had IL- 6 values higher than normal, while in the group with severe infection $76.19 \%$ of the patients had their value increased. Although not completely clarified, it is considered possible that such a process occurs due to the inhibition of Th2 cells participating in humoral immunity in the earliest stage of Covid-19. ${ }^{28}$

\section{Effects of severe hypoxemia on the liver}

There are three main risk factors that generate severe hypoxemia in patients who progress to liver involvement: heart failure, severe sepsis, and respiratory failure. ${ }^{29,30}$ Under these circumstances, a cytokine storm impairs the proper functioning of the liver, hindering transduction for cell survival, and causes significant accumulation of lipids, as well as increased consumption of glycogen and depletion of adenosine triphosphate from hepatocytes. Such associated factors cause oxidative stress and an increase in proinflammatory factors. ${ }^{27,31,32}$

As a consequence, patients develop a circulatory disorder resulting from passive congestion and decreased hepatic perfusion, which leads to hypoxia and ischemia. ${ }^{33}$ With liver damage installed, intracellular swelling of the organelle will be present. To reduce such negative effects, Kupffer cells increase the production of cytokines for leukocyte activation, which promotes increased levels of transaminase and lactate dehydrogenase (LDH), generating the need for oxygen support. ${ }^{3}$

Fig. 1 demonstrates the simultaneous action of the mechanisms of liver injury with the invasion of Sars-Cov- 2 in hepatocytes and cholangiocytes, causing irreversible dysfunctions, with consequent cell death.

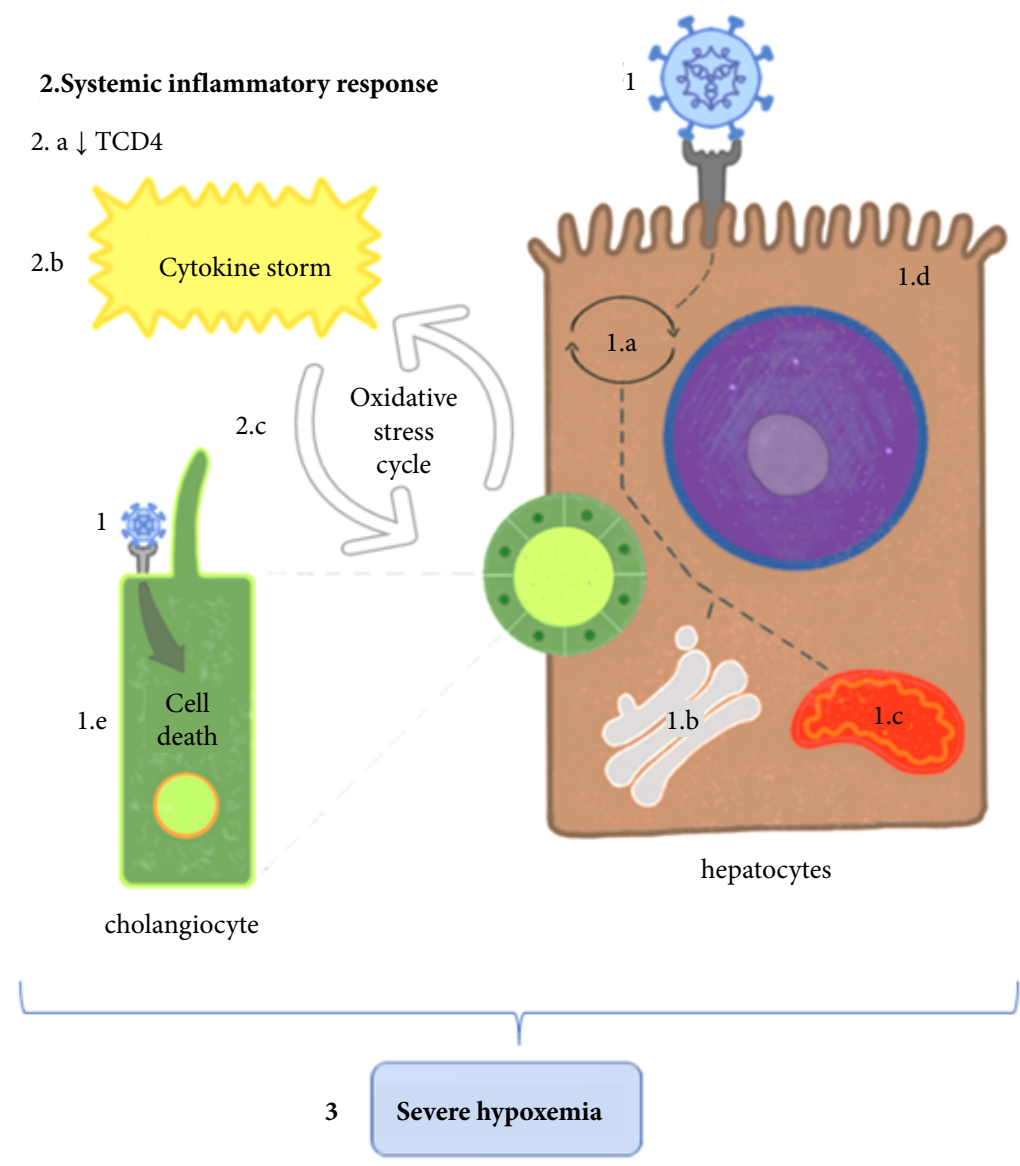

Figure 1. (1) The Sars-CoV-2 virus enters the cell by binding to the angiotensin-converting enzyme 2 (ACE2) expressed on the surface of hepatocytes and cholangiocytes. (1.a) Viral replication. (1.b) Endoplasmic reticulum stress. (1.c) Mitochondrial edema. (1.d) Cell membrane injury. (1.e) Cell death due to irreversible damage to organelles. (2) Systemic inflammatory response. (2.a) Lymphopenia characterized by a fall in the TCD4 lymphocyte count. (2.b) Exacerbated increase in inflammatory

cytokines. (2.c) Oxidative stress cycle: the pro-inflammatory environment created by cytokines hinders the process of

cellular respiration, thus damaging the liver cell. As a result, there is a further increase in pro-inflammatory factors. (3)

Severe hypoxemia, as a result of circulatory disturbance caused by the inflammatory environment and dysfunctional cells. 


\section{Evolution and prognosis}

Patients with severe Covid-19 without preexisting liver comorbidities take about three weeks to start developing liver damage. However, previously cirrhotic patients in a compensated state who are affected by the infection have an accelerated progression of liver damage, and decompensation or evolution of the injury may be noticeable with acute chronic liver failure since the first week. ${ }^{34,35}$

In these patients, it is possible to observe an increase in pro-inflammatory cytokines, associated with the presence of inflammatory markers of liver injury, weighted by the increase in the level of gamma-glutamyltransferase, ALT and AST proteins in the bloodstream. These proteins were measured as markers in studies with cirrhotic patients with Sars-CoV-2, in addition to the presence of leukopenia, lymphopenia and thrombocytopenia in laboratory tests. ${ }^{35-37}$

As a result of the liver involvement caused by the Covid-19virus, the controlled cirrhotic patient can progress to a decompensation condition. In this way, there is greater damage to the patient's liver and the chances of survival are reduced. ${ }^{38} \mathrm{~A}$ study was carried out based on cadaveric examinations of patients who died from decompensated cirrhosis and found that the invasion of liver cells by the Covid-19 virus, associated with mitochondrial edema and cell membrane damage, therefore causes apoptosis of the hepatocytes, significant focal lobular inflammation and important lymphocyte infiltrate. ${ }^{39}$

The association of liver cirrhosis with the new coronavirus was related to higher positions of liver severity in the international assessment represented by the Child-Pugh system, with $1 / 3$ of patients being reclassified into more severe categories. ${ }^{40}$ Assessment systems for patients with chronic liver disease are directly proportional to mortality from Sars-CoV-2. That is, patients classified as high Child-Pugh are more likely to die..$^{41-43}$

In this way, it is validated that patients pre-diagnosed with cirrhosis and infected with the Covid-19 virus have greater liver involvement and worse prognosis. ${ }^{37,38,40,41,43,46}$

\section{AUTHORS' CONTRIBUTION}

Substantive scientific and intellectual contributions to the study: Nascimento FBM; Fabris GM; Souza FG; Castro MS; Oliveira MEC; Silva VS and Buri R; Conception and design: Nascimento FBM; Fabris GM; Souza FG; Castro MS; Oliveira MEC; Silva VS and Buri R; Analysis and interpretation of data: Silva VCB; Castro MS; Lima MKZ; Zattar AK; Jesus VN; Oliveira MEC; Silva VS; Rodrigues LO and Buri R; Manuscript writing: Nascimento FBM; Fabris GM; Silva VCB; Castro MS; Lima MKZ; Zattar AK; Jesus VN; Oliveira MEC; Silva VS; Rodrigues LO and Buri R; Final approval: Nascimento FBM; Castro MS; Zattar AK; Oliveira MEC; Silva VS and Buri R.

\section{AVAILABILITY OF RESEARCH DATA}

Not applicable.

\section{FUNDING}

Not applicable.

\section{ACKNOWLEDGEMENTS}

Not applicable.

\section{CONCLUSION}

Liver findings are common in Covid-19 infection, caused by direct cytotoxicity, immune-mediated injury, hypoxemic effects, and also by the use of drugs for treatment, but there was no precise confirmation as to the direct effects on the death of patients infected by Sars-CoV-2 demonstrated in autopsy exams. ${ }^{23}$ Patients with preexisting liver diseases deserve special monitoring, since the clinical 
changes in the liver are more intense than normal, representing a worse prognosis and increased mortality in decompensated liver disease patients. ${ }^{40}$ Based on the information collected, the management and treatment of Covid-19 in patients should be carefully evaluated in order to reduce the liver damage caused by Sars-CoV-2.

\section{REFERENCES}

1. Zhu N, Zhang D, Wang W, Li X, Yang B, Song J, et al. A novel coronavirus from patients with pneumonia in China, 2019. New Eng J Med. 2020;382(8):727-33. https://doi.org/10.1056/NEJMoa2001017

2. Chan JFW, Yuan S, Kok KH, To KKW, Chu H, Yang J, et al. A familial cluster of pneumonia associated with the 2019 novel coronavirus indicating person-to-person transmission: a study of a family cluster. The Lancet. 2020;395(10223):514-23. https://doi.org/10.1016/s0140-6736(20)30154-9

3. Wang D, Hu B, Hu C, Zhu F, Liu X, Zhang J, et al. Clinical characteristics of 138 hospitalized patients with 2019 novel coronavirus-infected pneumonia in Wuhan, China. JAMA. 2020;323(11):1061-9. https://doi.org/10.1001/jama.2020.1585

4. Vaduganathan M, Vardeny P, Michel T, McMurray JJV, Pfeffer MA, Solomon SD. Renin-angiotensin-aldosterone system inhibitors in patients with Covid-19. N Engl J Med. 2020;382(17):1653-9. https://doi.org/10.1056/nejmsr2005760

5. Ye M, Wysocki J, William J, Soler MJ, Cokic I, Batlle D. Glomerular localization and expression of angiotensin-converting enzyme 2 and angiotensin-converting enzyme: Implications for albuminuria in diabetes. J Am Soc Nephrol. 2006;17(11):306775. https://doi.org/10.1681/asn.2006050423

6. Dweck MR, Bularga A, Hahn RT, Bing R, Lee KK, Chapman AR, et al. Global evaluation of echocardiography in patients with COVID-19. Eur Heart J Cardiovasc Imaging. 2020;21(9):949-58. https://oi.org/10.1093/ehjci/jeaa178

7. Cheng Y, Luo R, Wang K, Zhang M, Wang Z, Dong L, et al. Kidney disease is associated with in-hospital death of patients with COVID-19. Kidney Int. 2020;97(5):829-38. https://doi.org/10.1016/j.kint.2020.03.005

8. Mao L, Jin H, Wang M, Hu Y, Chen S, He Q, et al. Neurologic manifestations of hospitalized patients with coronavirus disease 2019 in Wuhan, China. JAMA Neurol. 2020;77(6):683-90. https://doi.org/10.1001/jamaneurol.2020.1127

9. Bernal-Monterde V, Casas-Deza D, Letona-Giménez L, Llama-Celis N de la, Calmarza P, Sierra-Gabarda O, et al. SARS-CoV-2 infection induces a dual response in liver function tests: Association with mortality during hospitalization. Biomedicines. 2020;8(9):328. https://doi.org/10.3390/biomedicines8090328

10. Guan W, Ni Z, Hu Y, Liang W, Ou C, He J, et al. Clinical characteristics of coronavirus disease 2019 in China. New Engl J Med. 2020;382(18):1708-20. https://doi.org/10.1056/NEJMoa2002032

11. Chen N, Zhou M, Dong X, Qu J, Gong F, Han Y, et al. Epidemiological and clinical characteristics of 99 cases of 2019 novel coronavirus pneumonia in Wuhan, China: a descriptive study. The Lancet. 2020;395(10223):507-13. https://doi.org/10.1016/ s0140-6736(20)30211-7

12. Cai Q, Huang D, Yu H, Zhu Z, Xia Z, Su Y, et al. COVID-19: Abnormal liver function tests. J Hepatol. 2020;73(3):566-74. https://doi.org/10.1016/j.jhep.2020.04.006

13. World Health Organization. Mission China Joint. Report of the WHO-China Joint Mission on coronavirus disease 2019 (COVID-19). The WHO-China Joint Mission on Coronavirus Disease 2019. World Health Organization; 2020.

14. Galvão MHR, Roncalli AG. Factors associated with increased risk of death from covid-19: A survival analysis based on confirmed cases. Rev Bras Epidemiol. 2021;23:e200106. https://doi.org/10.1590/1980-549720200106

15. Bellentani S, Saccoccio G, Costa G, Tiribelli C, Manenti F, Sodde M, et al. Drinking habits as cofactors of risk for alcohol induced liver damage. Gut. 1997;41(6):845-50. https://doi.org/10.1136/gut.41.6.845

16. Poynard T, Bedossa P, Opolon P. Natural history of liver fibrosis progression in patients with chronic hepatitis C. The Lancet. 1997;349(9055):825-32. https://doi.org/10.1016/s0140-6736(96)07642-8

17. Farrell GC, Larter CZ. Nonalcoholic fatty liver disease: from steatosis to cirrhosis. Hepatology. 2006;43(2 Suppl. 1):S99-S112. https://doi.org/10.1002/hep.20973

18. Sarin SK, Choudhury A, Lau GK, Zheng MH, Ji D, Abd-Elsalam S, et al. Pre-existing liver disease is associated with poor outcome in patients with SARS CoV2 infection; The APCOLIS Study (APASL COVID-19 Liver Injury Spectrum Study). Hepatology Int. 2020;14(5):690-700. https://doi.org/10.1007/s12072-020-10072-8

19. Lei P, Zhang L, Han P, Zheng C, Tong Q, Shang H, et al. Liver injury in patients with COVID-19: clinical profiles, CT findings, the correlation of the severity with liver injury. Hepatol Int. 2020;14(5):733-42. https://doi.org/10.1007/s12072-020-10087-1

20. Li W, Moore MJ, Vasilieva N, Sui J, Wong SK, Berne MA, et al. Angiotensin-converting enzyme 2 is a functional receptor for the SARS coronavirus. Nature. 2003;426(6965):450-4. https://doi.org/10.1038/nature02145

21. Hamming I, Timens W, Bulthuis MLC, Lely AT, Navis GJ, van Goor H. Tissue distribution of ACE2 protein, the functional receptor for SARS coronavirus. A first step in understanding SARS pathogenesis. J Pathol. 2004;203(2):631-7. https://doi.org/10.1002/path.1570 
22. Chai X, Hu L, Zhang Y, Han W, Lu Z, Ke A, et al. Specific ACE2 expression in cholangiocytes may cause liver damage after 2019-nCoV infection. BioRxiv. 2020. https://doi.org/10.1101/2020.02.03.931766

23. Xu Z, Shi L, Wang Y, Zhang J, Huang L, Zhang C, et al. Pathological findings of COVID-19 associated with acute respiratory distress syndrome. Lancet Respir Med. 2020;8(4):420-2. https://doi.org/10.1016/s2213-2600(20)30076-X

24. Wang D, Hu B, Hu C, Zhu F, Liu X, Zhang J, et al. Clinical characteristics of 138 hospitalized patients with 2019 novel coronavirus-infected pneumonia in Wuhan, China. JAMA. 2020;323(11):1061-9. https://doi.org/10.1001/jama.2020.1585

25. Wang Y, Liu S, Liu H, Li W, Lin F, Jiang L, et al. SARS-CoV-2 infection of the liver directly contributes to hepatic impairment in patients with COVID-19. J Hepatol. 2020;73(4):807-16. https://doi.org/10.1016\%2Fj.jhep.2020.05.002

26. Zhang C, Shi L, Wang FS. Liver injury in COVID-19: management and challenges. Lancet Gastroenterol Hepatol. 2020;5(5):428-30. https://doi.org/10.1016/s2468-1253(20)30057-1

27. Liu J, Li S, Liu J, Liang B, Wang X, Wang H, et al. Longitudinal characteristics of lymphocyte responses and cytokine profiles in the peripheral blood of SARS-CoV-2 infected patients. Ebiomedicine. 2020;55:102763. https://doi.org/10.1016/j.ebiom.2020.102763

28. Wan S, Yi Q, Fan S, Lv J, Zhang X, Guo L, et al. Characteristics of lymphocyte subsets and cytokines in peripheral blood of 123 hospitalized patients with 2019 novel coronavirus pneumonia (NCP). Medrxiv. https://doi.org/10.1101/2020.02.10.20021832

29. Birrer R, Takuda Y, Takara T. Hypoxic hepatopathy: pathophysiology and prognosis. Intern Med. 2007;46(14):1063-70. https://doi.org/10.2169/internalmedicine.46.0059

30. Wong CK, Lam CWK, Wu AKL, Ip WK, Lee NLS, Chan IHS, et al. Plasma inflammatory cytokines and chemokines in severe acute respiratory syndrome. Clin Exp Immunol. 2004;136(1):95-103. https://doi.org/10.1111/j.1365-2249.2004.02415.x

31. Kulkarni A, Kumar P, Tevethia HV, Premkumar M, Arab JP, Candia R, et al. Systematic review with meta-analysis: liver manifestations and outcomes in COVID-19. Aliment Pharmacol Ther. 2020;52(4):584-99. https://doi.org/10.1111/apt.15916

32. Bloom PP, Meyerowitz EA, Reinus Z, Daidone M, Gustafson J, Kim AY, et al. Liver Biochemistries in Hospitalized Patients With COVID-19. Hepatology. 2021;73(3):890-900. https://doi.org/10.1002/hep.31326

33. Varga Z, Flammer AJ, Steiger P, Haberecker M, Andermatt R, Zinkernagel AS, et al. Endothelial cell infection and endotheliitis in COVID-19. Lancet. 2020;395(10234):1417-8. https://doi.org/10.1016/s0140-6736(20)30937-5

34. Sarin SK, Choudhury A, Lau GK, Zheng M-H, Ji D, Abd-Elsalam S, et al. Pre-existing liver disease is associated with poor outcome in patients with SARS CoV2 infection; The APCOLIS Study (APASL COVID-19 Liver Injury Spectrum Study). Hepatol Int. 2020;14(5):690-700. https://doi.org/10.1007/s12072-020-10072-8

35. Ji D, Zhang D, Yang T, Mu J, Zhao P, Xu J, et al. Effect of COVID-19 on patients with compensated chronic liver diseases. Hepatol Int. 2020;14(5):701-10. https://doi.org/10.1007/s12072-020-10058-6

36. Marjani A, Mehrpouya M, Pourhashem Z. Serum $\gamma$-glutamyltransferase, alanine aminotransferase and aspartate aminotransferase activity in healthy blood donor of different ethnic groups in Gorgan. J Clin Diagn Res. 2016;10(7):BC04-6. https://doi.org/10.7860\%2FJCDR\%2F2016\%2F20919.8181

37. Melo APS, França EB, Malta DC, Garcia LP, Mooney M, Naghavi M. Mortalidade por cirrose, câncer hepático e transtornos devidos ao uso de álcool: Carga Global de Doenças no Brasil, 1990 e 2015. Rev Bras Epidemiol. 2017;20(Supl. 1):61-74. https://doi.org/10.1590/1980-5497201700050006

38. Kim D, Adeniji N, Latt N, Kumar S, Bloom PP, Aby ES, et al. Predictors of outcomes of COVID-19 in patients with chronic liver disease: US multi-center study. Clin Gastroenterol Hepatol. 2021;19(7):1469-79. https://doi.org/10.1016/j.cgh.2020.09.027

39. Rela M, Patil V, Narasimhan G, Jothimani D. COVID-19 in decompensated cirrhosis. Hepatol Int. 2020;14(6):1125-7. https:// doi.org/10.1007/s12072-020-10092-4

40. Qi X, Liu Y, Wang J, Fallowfield JA, Wang J, Li X, et al. Clinical course and risk factors for mortality of COVID-19 patients with pre-existing cirrhosis: A multicentre cohort study. Gut. 2021;70(2):433-6. https://doi.org/10.1136/gutjnl-2020-321666

41. Iavarone M, D’Ambrosio R, Soria A, Triolo M, Pugliese N, del Poggio P, et al. High rates of 30-day mortality in patients with cirrhosis and COVID-19. J Hepatol. 2020;73(5):1063-71. https://doi.org/10.1016/j.jhep.2020.06.001

42. Marjot T, Moon AM, Cook JA, Abd-Elsalam S, Aloman C, Armstrong MJ, et al. Outcomes following SARS-CoV-2 infection in patients with chronic liver disease: An international registry study. J Hepatol. 2021;74(3):567-77. https://doi.org/10.1016/j.jhep.2020.09.024

43. Qi X, Wang J, Li X, Wang Z, Liu Y, Yang H, et al. Clinical course of COVID-19 in patients with pre-existing decompensated cirrhosis: initial report from China. Hepatol Int. 2020;14(4):478-82. https://doi.org/10.1007/s12072-020-10051-Z

44. Shalimar, Elhence A, Vaishnav M, Kumar R, Pathak P, Soni KD, et al. Poor outcomes in patients with cirrhosis and corona virus disease-19. Indian J Gastroenterol. 2020;39(3):285-91. https://doi.org/10.1007/s12664-020-01074-3

45. Bajaj JS, Garcia-Tsao G, Biggins SW, Kamath PS, Wong F, McGeorge S, et al. Comparison of mortality risk in patients with cirrhosis and COVID-19 compared with patients with cirrhosis alone and COVID-19 alone: multicentre matched cohort. Gut. 2021;70(3):531-6.

46. Hashemi N, Viveiros K, Redd WD, Zhou JC, McCarty TR, Bazarbashi AN, et al. Impact of chronic liver disease on outcomes of hospitalized patients with COVID-19: A multicentre United States experience. Liver Int. 2020;40(10):2515-21. https://doi. org/10.1111/liv.14583 